\title{
Domestic Violence among Married Females: Prevalence and Related Factors
}

\author{
Manpreet $\operatorname{Kaur}^{1}{ }^{*}$, Deepika Kapoor ${ }^{2}$, Jatinder Kaur ${ }^{3}$, Pallvi Gautam ${ }^{4}$, Setika \\ Sharma $^{5}$, Sushma K. Saini ${ }^{6}$, Suresh K. Bamania ${ }^{7}$
}

\section{ABSTRACT}

Violence against women is present across the world cutting across boundaries of culture, class, education, income, ethnicity and age. It is the most prevalent yet relatively hidden and ignored form of violence. The present descriptive study was conducted to assess the prevalence of domestic violence among married females of Daddu Majra colony, Chandigarh. An Interview schedule was used for data collection validated by ten experts in the field of nursing and sociology. Total 300 females of age group 18-60 are selected by systematic random sampling. House to House survey of every tenth selected house was done and married females were screened for domestic violence through screening Performa, interviewed in their houses as per Interview schedule after taking written consent .Confidentiality of subjects was maintained .Results indicated the overall prevalence of domestic violence was $27.67 \%$. Prevalence of physical violence was $16 \%$, psychological violence was $22.67 \%$, financial violence was $7.67 \%$ and sexual violence was $7 \%$.The most common cause found behind domestic violence was alcohol intake by husband. Extramarital affair of husband, not doing household work by women were other common factors. The most common abuser was husband and mother-in-law. Most of the women interviewed were not having any knowledge about women's right, emergency women helpline number and laws for women. So it is recommended that emphasis should be made on educating the females about their rights, laws for them and helpline during emergency.

Keywords: Family Planning, Attitude, Different Religion, Genders, Life Stress

\footnotetext{
${ }^{1}$ National Institute of Nursing Education, PGIMER, Chandigarh, India

${ }^{2}$ National Institute of Nursing Education, PGIMER, Chandigarh, India

${ }^{3}$ National Institute of Nursing Education, PGIMER, Chandigarh, India

${ }^{4}$ National Institute of Nursing Education, PGIMER, Chandigarh, India

${ }^{5}$ National Institute of Nursing Education, PGIMER, Chandigarh, India

${ }^{6}$ Lecturer, National Institute of Nursing Education, PGIMER, Chandigarh, India

${ }^{7}$ National Institute of Nursing Education, PGIMER, Chandigarh, India

*Responding Author

(C) 2016, M Kaur, D Kapoor, J Kaur, P Gautam, S Sharma, S Saini, S Bamania; licensee IJIP. This is an Open Access Research distributed under the terms of the Creative Commons Attribution License (http://creativecommons.org/licenses/by/2.0), which permits unrestricted use, distribution, and reproduction in any Medium, provided the original work is properly cited.
} 


\section{Domestic Violence among Married Females: Prevalence and Related Factors}

India where almost half of the population are women they have always been ill-treated and deprived of their right to life and personal liberty as provided under the Constitution of India. Women are always considered as a physically \& emotionally weaker than males, whereas at present women have proved themselves in almost every field affirming that they are not less than men due to their hard work whether at home or working places. According to a latest report prepared by India's National Crime Records Bureau (NCRB), a crime has been recorded against women in every three minutes in India. Every 60 minutes two women are raped in this country. Every 6 hrs, a young married woman is found beaten to death, burnt or driven to suicide. The statistics of increasing crimes against women is shocking, where women are subjected to violence attacks that is feticide, medical neglect, infanticide, bride burning, sexual abuse of girl child, forced marriages, rapes, prostitutions, sexual harassment at home as well as work place etc. In all the above cases women is considered as aggrieved person. The term used to describe this exploding problem of violence within our homes is ‘Domestic Violence' (Pahuja, 2011).

Domestic violence is the willful intimidation, physical assault, battery, sexual assault and/or other abusive behaviour as part of a systematic pattern of power and control perpetrated by one intimate partner against another. It includes physical violence, sexual violence, psychological violence and emotional abuse. The frequency and severity of domestic violence can vary dramatically; however, the one constant component of Domestic violence is one partner's consistent efforts to maintain power and control over the other. Domestic violence is an epidemic affecting individuals in every community, regardless of age, economic status, sexual orientation, gender, race, religion or nationality. (What is domestic violence?, 2011)

Violence is quite common against the educated and well placed women, the pattern of such violence differs from class to class .At the "Bustee" (or slum) level there is nothing private in the husband beating his wife because half of the neighbourhood witness the act. However in middle or upper classes, it is private affair and the lady tries to hide it from other. In most cases women accept it as their fate, but in some cases, where they resist and protest, the beatings become more and more severe with time. Women always suffer in silence and suffer from physical abuse filled with terror and pain (Ahuja, 1987).

According to India's National Family Health Survey-3, which interviewed 1.25 lakh women in 28 states during 2005-06, over $40 \%$ of women reported being beaten by their husbands at some point of time. Over 51\% of the 75000 men interviewed did not find anything wrong with assaulting their wives. More shockingly around 54\% of women surveyed thought that such violence was justified on one ground or the other (NFHS-3,2007).

In 1983, Domestic violence was recognized as a specific criminal offence by the introduction of section 498-A into the Indian Penal Code. This section deals with cruelty by a husband or his family towards a married woman. Four types of cruelty are dealt with by this law- 


\section{Domestic Violence among Married Females: Prevalence and Related Factors}

1. Conduct that is likely to drive a woman to suicide.

2. Conduct which is likely to cause grave injury to the life, limb or health of the woman.

3. Harassment with the purpose of forcing the woman or her relatives to give some property.

4. Harassment because the woman or her relatives is unable to yield to demands for more money or does not give some property.

The punishment is imprisonment for up to three years and a fine. The complaint against cruelty need not be lodged by the person herself. Any relative may also make the complaint on her behalf.

The Protection of Women from Domestic violence Act 2005 is an Act of Parliament of India enacted to protect women from domestic violence. It was brought into force by the Indian govt. from 26 October 2006. The Act provides for the first time in Indian law a definition of "domestic violence"', with this definition being broad and including not only physical violence but also other forms of violence such as emotional/verbal, sexual and economic abuse. It is civil law meant primarily for protection orders and not meant to penalize criminally.

In this great land where non violence has been preached and practiced as a way of life for thousands of years and where women have been adored in the images of goddess Saraswati for enlightenment, Durga or Kali for physical powers and Laxmi for wealth, women today are crying for justice from widespread violence of varied kinds that has perpetrated against them within and outside their households, right from their conception in wombs up to their deaths(NFHS-3, 2007).

In India the nature and extent of women abuse has not received adequate attention primarily because of lack of sensitivity to the problem in our country. This has considerably contributed to the prevailing dearth of data on the nature and magnitude of the problem which in turn creates difficulties in formulating intervention for its management and prevention. Further, most of the cases are neither reported nor published. Despite this, observation of professionals and finding of

studies conducted by social scientists and medical practitioners provide a definite clue to the widespread prevalence of woman abuse in variety of forms all over the country.

Domestic violence is not a new phenomenon but because of lack of awareness and other factors such as fear of expulsion from the home, societal influence, legal problems etc. till date it is underreported and underestimated. In many communities, domestic violence is a routine practice. Many women are not even aware that they are being abused or it is illegal. After the enforcement of act against domestic violence many people become aware of it.

But only few researches have been conducted in this area as it is generally assumed that women will not open up to respond and it is a very sensitive issue.

(c) The International Journal of Indian Psychology, ISSN 2348-5396 (e) | ISSN: 2349-3429 (p) | 7 


\section{Domestic Violence among Married Females: Prevalence and Related Factors}

But as a health professional, during our posting in community setting, we come across many cases of domestic violence where women are the primary victim, being abused in one or the other way by their family members. During our home visits, many women discuss their experiences and incidences about domestic violence. But because of lack of awareness women avoid to take further steps to stop violence against them. A study is needed to assess the magnitude of the problem in the community as well as the impact of related factors on its prevalence. By this descriptive study we will be able to plan educational programs and other strategies to make women aware of it in future so that effective measures can be taken to reduce domestic violence.

\section{Objectives of the study}

1. To assess the prevalence of domestic violence among married females of age group 1860 years of Daddu Majra Colony, Chandigarh.

2. To assess the factors associated with domestic violence among married females of age group 18-60 years of Daddu Majra Colony, Chandigarh.

\section{MATERIAL AND METHODS}

This was a descriptive study to assess the prevalence of domestic violence among married females and related factors among families residing in Daddu Majra Colony, Chandigarh. The sample size for the present study was 300 married females of age group 18-60years. The sampling technique used for the selection of the subjects was systematic random sampling i.e. every $10^{\text {th }}$ house in Daddu Majra Colony. First house was selected by lottery method and was house number 2 and every $10^{\text {th }}$ house was selected subsequently. The tool consisted of screening Performa to identify women experiencing violence and interview schedule. The interview schedule consisted of 3 parts: part A- socio-demographic data, B-question about different types of violence, C-questions about management of violence. The tool validation was done by 10 experts from the field of nursing and sociology. The ethical clearance for conducting the study was obtained from the departmental ethical committee. The data was collected over a period of 10 days in the first week of April by 5 researchers with door to door visit. For the data collection, each subject was contacted in their house and screening for domestic violence was done as per the screening Performa. Then the screened females were interviewed as per the interview schedule. Before starting interview written informed consent was taken from the subjects. The females were interviewed in separate room and privacy was maintained. They were insured about the confidentiality of information collected from them. It took 20-25 minutes for the commencement of each interview. The data was analyzed using both descriptive and inferential statistics. Calculations were carried out manually and using SPSS. The findings were interpreted and presented with the help of tables and figure. 


\section{RESULTS}

\section{Participant Characteristics}

Women were in the range of 19-60 years with mean age of 35.65+9.50years and their husbands were in the range of $21-71$ years with mean age of $39.07+9.95$ years. $42 \%$ of female and $40 \%$ of their husbands were in the age group of 31-40 years, one fourth of the female population (24\%) has completed their middle school education and one fourth of the husbands (28\%) had completed matriculation. Only a small proportion of women (6.3\%) and husbands (4.3\%) were illiterate. Majority of women (84.7\%) were housewife and half of the husbands (50.0\%) were in private job.

Half of the participants (51\%) belonged to scheduled caste/ scheduled tribe and nearly half (42\%) to general and 7\% belonged to backward classes. Most of the participants (86.70\%) were Hindu and a small proportion (5\%) was of other religions. Majority (92.70\%) were currently married. Marriage duration of one third subjects (36.33\%) was 1-10 years and another one third (30.33\%) marriage duration was $11-20$ years. Two third of participants (70\%) had Rs. 5011000/- per capita income and only a small percentage(7\%) has per capita income more than Rs.1000. Half of the participants (54.34\%) belonged to nuclear family. Majority (80.7\%) were from families with 3-7 numbers of family members. And $79.70 \%$ of the participants were having their own houses.

Majority (98.3\%) of the females and more than half of their husbands (59.3\%) were not addicted to any substance. One percent of the women were taking substance in the form of paan, jarda, hookah etc., $0.7 \%$ were smoking. One third of husbands (32\%) were taking alcohol, out of which $48 \%$ were taking alcohol only and others were taking it with some other substance (52\%), one fourth of husbands (23\%) were smokers either alone $(32.8 \%)$ or with some other substance (61.2\%), 3\% were consuming alcohol, smoking as well as other substances(paan, jarda).

\section{Prevalence and related factors of domestic violence}

Figure 1 depicts the overall prevalence of different types of domestic violence among the 300 study participants of Daddu Majra colony. The overall prevalence of domestic violence is $27.67 \%$ and psychological violence $(22.67 \%)$ is the most prevalent one. The prevalence of physical violence is $16 \%$, financial violence is $7.67 \%$ and sexual violence is $7 \%$. More than one type of violence was found among some participants.

Table 1 represents the causes of domestic violence among married females of Daddu Majra Colony. Alcohol intake by husband is the major cause of domestic violence both in physical violence (58.33\%) and psychological violence (45.59\%). In 8\% cases, infertility in the women was the cause behind physical and emotional violence. In one fourth cases (26.47\%) of psychological violence, not doing the household work by woman was the cause. In $10 \%$ cases the extramarital affair of the husband was the cause behind violence against women. Other

(C) The International Journal of Indian Psychology, ISSN 2348-5396 (e)| ISSN: 2349-3429 (p) | 9 


\section{Domestic Violence among Married Females: Prevalence and Related Factors}

causes of violence were instigation by other family members $(12.50 \%)$, mental illness of husband (2.08\%), not getting involved in sexual acts with husband (2.08\%). In 2.08\% cases women experienced violence after spouse death. Females also experienced domestic violence due to dispute over property with other family members (8.33\%).

Table 2 reveals the characteristics of different types of violence among married females of Daddu Majra Colony. In physical violence, slapping on the cheeks/head/ back was common in all the cases and in half of the cases (56.25\%) pulling by hairs/ear/arms/leg was used and $47.92 \%$ were pushed/thrown things/ choked and $2 \%$ reported burning any body part. In psychological violence, using inappropriate words against her and her relatives (69.12\%) is the most common one, with saying/doing anything to humiliate her in front of family members (67.65\%) was the $2^{\text {nd }}$ most common method. Insulting or making her feel inferior in front of others $(64.70 \%)$ was also very common in psychological violence. In financial violence, taken money forcibly (60.87\%) is more prevalent. In half of the cases (56.52\%) valuables were taken away from her against her wish. In sexual violence, husband had sexual contact against her will in all the cases. In $10 \%$ cases, any other family member forced her for sexual contact against her wish.

Table 3 indicates the relationship of the perpetrator with female. Husband is the main perpetrator in the three types of violence i.e. physical violence (91.67\%), psychological violence (75\%) and in all cases of sexual violence. Mother- in- law acted as perpetrator in $8 \%$ cases of physical abuse and $29 \%$ cases of psychological abuse. Daughter- in- law was responsible for $2 \%$ cases of physical violence and $4 \%$ cases of psychological violence. In $12.50 \%$ cases of psychological violence, children were the perpetrator. Father- in- law (10\%) and brother- in- law (10\%) were responsible for sexual violence.

More than half of the victims (58\%) did nothing at all after experiencing violence. One fourth (24.10\%) of the cases took advice from the parents. One percent took legal action against the perpetrator and 5\% got separated from the family member causing violence. One percent took advice from the doctor. Fourteen percent of women have knowledge related to women's right, $37 \%$ have knowledge related to emergency number/helpline number and $24 \%$ have knowledge related to laws for women.

Table4 depicts association between socio demographic variables and prevalence of domestic violence. The prevalence of domestic violence was higher among scheduled caste/tribe (57.8\%) than general caste (39.8\%) and other backward classes (2.4\%), though statistically there is no significant association between the caste of participant and domestic violence as per chi square test ( $>0.05$ ). There is significantly higher prevalence of domestic violence in the families with per capita income more than Rs. 500/- (68.7\%) than families with per capita income less than Rs. 500. (as per chi square test $\mathrm{p}<0.05$ ). Domestic violence was significantly higher among women of Hindu religion (84.3\%) as compared to the others (as per chi square test $\mathrm{p}<0.05$ ). Among

(C) The International Journal of Indian Psychology, ISSN 2348-5396 (e)| ISSN: 2349-3429 (p) | 10 


\section{Domestic Violence among Married Females: Prevalence and Related Factors}

couples with duration of marriage 1-10 years (38.6\%), families having members 3-7 (78.3\%), nuclear families (57.8\%) ,families with own houses (80.7\%)had higher prevalence of domestic violence as compared to their counterparts but no statistically significant association was found as per chi square test $(\mathrm{p}>0.05)$

Table 5 depicts the association between prevalence of domestic violence and age, education and occupation of husband and wife. Domestic violence is more prevalent among age group 31-40 years of husband $(38.6 \%)$ and wife $(43.4 \%)$ as compared to other counter parts but no statistically significant association between age and domestic violence. Its prevalence is higher among housewife/unemployed (85.5\%) in case of females. Among husband it is more prevalent among private job workers (49.4\%), though no statistically significant association between the occupation status and domestic violence. High prevalence is found among middle class education of husband (36.1\%) and wife (33.7\%) than other counterparts. And there is no significant association between the education of women and domestic violence but there is statistically significant association between the education of husband and domestic violence i.e. it is more prevalent among husbands with higher education status.

It is mostly prevalent in no substance using wives (97.6\%) and substance using husbands (68.7\%). There is significant association between the addiction of the husband and the domestic violence prevalence i.e. it is more in the females having substance using husbands than the counter parts. And its prevalence is $2.4 \%$ in mentally ill husbands but no statistical association between the mental illness and domestic violence.

\section{DISCUSSION}

The research on domestic violence referred to more precisely in academic literature as intimate partner violence has grown substantially over a past few decades. Although knowledge of the problem and its support has deepened, the issue remains a major health and social problem afflicting women.

The World Health Organization estimated that 35\% of all women have experienced either intimate partner violence or sexual violence by non-partner during their lifetime. This figure is supported by the findings of the 2012 peer reviewed metastudy -the most vigorous form of research analysis-published in the leading Academic journal Science. The metastudy found that in 2010, 30\% women aged 15 and over have experienced, during their lifetime, physical or sexual intimate partner violence (Human Rights Watch World Report-2012, Events of 2011, 2012). Similar results were found in our study which was conducted on 300 married females from Daddu Majra Colony, Chandigarh where the overall prevalence is $27.67 \%$; with $16 \%$ physical violence, $22.67 \%$ psychological violence, $7.67 \%$ financial violence and $7 \%$ sexual violence. Higher prevalence was reported by the study conducted by Gujarat Institute of 


\section{Domestic Violence among Married Females: Prevalence and Related Factors}

Development, where $42 \%$ experienced physical beating or sexual assault and 23\% experienced psychological violence study (Jejeebhoy, 1998).

In the current study, the prevalence is more among age group 31-40 years of females and is more prevalent among Hindus and scheduled caste/tribes and among women residing in nuclear families. Although it is believed that with increase in education the domestic violence level will reduce but in our study it was found more among middle level educated women who are either housewives or unemployed than in the illiterate women. Even more shocking finding was evident in our study that husbands with higher educational status were significantly more involved in domestic violence as compared to less educated. Prevalence of violence was significantly more in the families with per capita income more than Rs. 500/-. A cross sectional study was conducted in slums of Ludhiana that showed majority of married women who experienced domestic violence were illiterate and housewives and were in the nuclear families which is similar to the findings of our study (Kaur, Patidar et al 2014).

Husband and wife are believed to be the two wheels of the house without one the other cannot work independently. But the present study shows that the husbands were the main perpetrators in majority of the cases (91.67\% in physical violence and $75 \%$ in psychological violence). Substance use has many ill effects on the physical, psychological, financial aspects of human being and in our study it was also the major factor for inducing violence as $70 \%$ husbands who were the perpetrators were addicts (smoking, alcohol, paan , jarda etc.).

Today when we talk about women empowerment and equal status still women are undergoing physical torture as slapping was reported by all of the females as the specific act of physical violence and few of them also reported to be pulled by hair and choking. In few cases burning incidents of women by the family members was also reported. Psychological torture is worse than the physical even as it keeps on hurting all the time. In present study the use of inappropriate words against women and her relatives was very common among families. Even valuables were taken away from the women.

This study shows that women are themselves the enemies of women as Mother-in-law is herself involved in violence against their daughter-in-law. Also women are not safe in their own houses as they are undergoing violence by other family members (brother-in-law, sister-in-law).Even they are sexually abused by other family members than husbands.

The present study shows that $69.87 \%$ took no action against the perpetrator. In the sample of 300 females only $8 \%$ females were aware about the laws for women in India and only $12.30 \%$ females knew about the emergency or helpline numbers. The above findings can be explained by the concept of violence in Indian culture where violence against women is tolerated and considered as a means of discipline or punishment. Most probably, women do not protest or 


\section{Domestic Violence among Married Females: Prevalence and Related Factors}

retaliate against the harassments, out of their concerns for social prestige, lack of economic and social support and for the sake of their children. In recent years researchers have addressed the specific challenges of documenting the violence suffered by the women in conflict situations.

This study results show that despite the advancements obtained in recent years in the field, critical knots still persist in these women coping trajectories to break their silence, denounce and overcome the violence suffered. The government of India has made various ways to increase the knowledge of women regarding help in domestic violence like Women helpline numbers are displayed on buses, autos and at all public places. Still women are not aware of it. This study is expected to support the creation of helping strategies and make them more effective in order to strengthen the support network focused on violence against women. A crucial question in the light of the increasing instances of domestic violence is that what should be done to control and reduce it. As health professional and responsible citizens should we just sit and read articles and collect information about domestic violence or should we raise our voices against it? Today Domestic Violence is being viewed as an epidemic disease which needs to be controlled. Many law agencies, governmental and non-governmental organizations, public and private bodies are working for this cause.

It is recommended that emphasis should be made on educating the females about their rights, laws for them and helpline during emergency. There should be efforts towards the prevention of domestic violence in community by community participation. Community leaders should be mobilized for prevention of domestic violence and about the laws regarding domestic violence. At community level women should be empowered so that they can stand for themselves and educated about the laws and emergency helpline numbers related to domestic violence. It is necessary to develop programs for prevention of domestic violence in community. Community nurses should educate community about prevention of domestic violence. The similar study can be conducted on larger number of subjects and in different settings. There should be creation of small self-help groups of women to prevent domestic violence. And there should be collaboration between women association and community leader for prevention of domestic violence and helping the victims. Nurses working in community should organize programme for women empowerment to make them independent and also should be vigilant observers so that she can identify the cases of domestic violence in community setting. They should ensure that they will provide education about the prevention of domestic violence and also involve the community in prevention of domestic violence. Nurses may use these results to document the need for prevention of domestic violence in general population. Nurses must be aware about different agencies and services available for women experiencing domestic violence and should collaborate with those agencies for the prevention of domestic violence on women and social

helpline should be established for them. She can tell about different laws/acts against the domestic violence to females in community as well as they can organize awareness camps on it. Nurse should mobilize the community leaders of their areas in reducing the domestic violence 


\section{Domestic Violence among Married Females: Prevalence and Related Factors}

among females. She should counsel the victims and in extreme cases the victims should be referred to various self-help groups for guidance and counseling.

\section{Acknowledgments}

The author appreciates all those who participated in the study and helped to facilitate the research process.

\section{Conflict of Interests}

The author declared no conflict of interests.

\section{REFERENCES}

Ahuja, R. (1987). Crime Against Women. Jaipur: Rawat Publications.

Human Rights Watch World Report-2012 (Events of 2011).(2012).Retrieved from http://www.hrw.org/.../wr2011hook.

Jejeebhoy, J. S.(1998). Wife beating in rural India: A husband's right- Evidence from survey data. Economic and political weekly, 33(15), 855-62.

Kaur, S., Patidar, A. B., Meenakshi, Sharma, S., \& Navneet. (2014, January). Domestic violence and its contributory factors among married women in selected slums of Ludhiana, Punjab. Nursing and midwifery research journal, 10(1), 30-36.

NFHS-3: $40 \%$ of Indian women face domestic violence. (2007).Retrieved from http://www.infochangeindia.org/women/news/nfhs-iii-40-of-indian-women-facedomestic-violence.html

Pahuja, D. (2011). Domestic violence against women in India. Retrieved from http:// www.legalindia.com/domestic-violence-against-women-in-india

What is domestic violence? (2011). Retrieved from http://www.ncadv,org/need-help/what-isdomestic-violence

\section{APPENDIX}

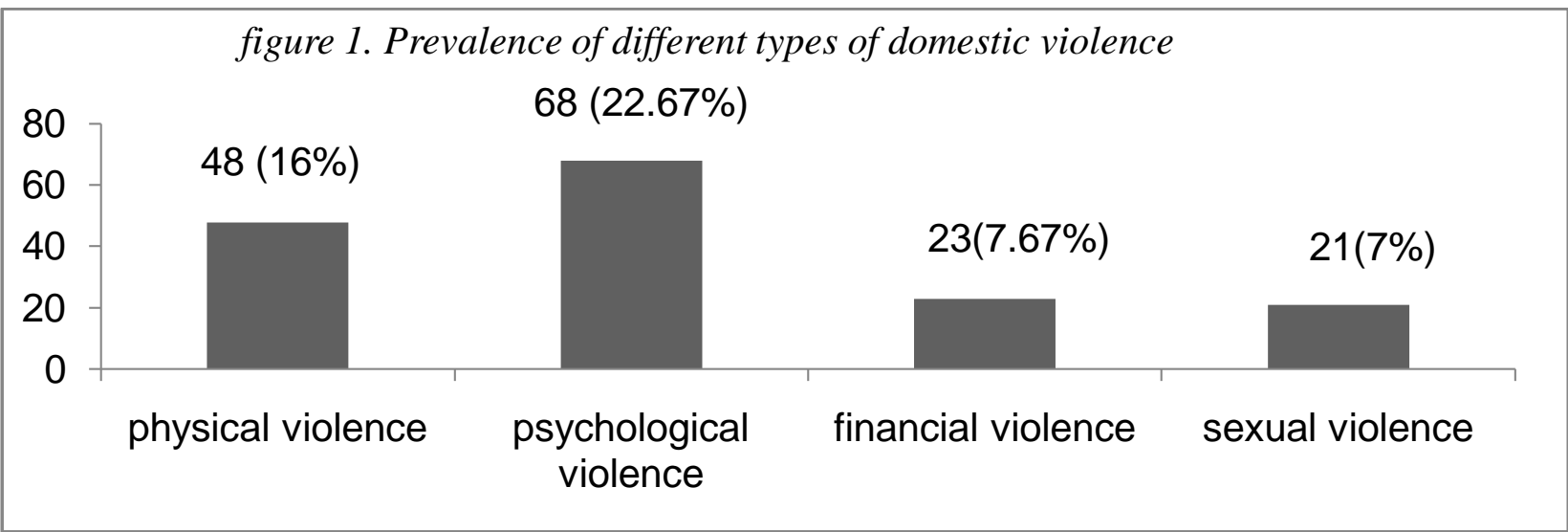

(c) The International Journal of Indian Psychology, ISSN 2348-5396 (e)| ISSN: 2349-3429 (p) | 14 
Table1, Causes of Domestic Violence among Married Females of Daddu Majra Colony

\begin{tabular}{|c|c|}
\hline Variable & n (\%) \\
\hline \multicolumn{2}{|l|}{ Physical violence $N=48$} \\
\hline \multicolumn{2}{|l|}{ factors related to husband } \\
\hline alcohol intake by husband & 28(58.33) \\
\hline extramarital affair of husband & $5(10.42)$ \\
\hline instigation by other family members & $6(12.50)$ \\
\hline mental illness of husband & $1(2.08)$ \\
\hline for not getting involved in sexual acts with husband & $1(2.08)$ \\
\hline \multicolumn{2}{|l|}{ factors related to wife } \\
\hline for not doing household work properly & $7(14.58)$ \\
\hline job of wife & $3(6.25)$ \\
\hline for dowry & $2(4.17)$ \\
\hline infertility in women & $4(8.33)$ \\
\hline after spouse's death & $1(2.08)$ \\
\hline \multicolumn{2}{|l|}{ miscellaneous } \\
\hline dispute over property with other family members & $4(8.33)$ \\
\hline no apparent reason & $1(2.08)$ \\
\hline \multicolumn{2}{|l|}{ Psychological violence $\mathrm{N}=68$} \\
\hline \multicolumn{2}{|l|}{ Factors related to husband } \\
\hline extramarital affair of husband & 7(10.29) \\
\hline under the influence of alcohol & $31(45.59)$ \\
\hline \multicolumn{2}{|l|}{ factors related to wife } \\
\hline for not doing household work & 18(26.47) \\
\hline for higher educational status of wife than husband & $1(1.47)$ \\
\hline infertility in women & $6(8.82)$ \\
\hline excessive use of money by the wife on herself & $14(20.59)$ \\
\hline no apparent reasons & $3(4.41)$ \\
\hline
\end{tabular}

Table 2 Characteristics of Different Types of Violence among Married Females of Daddu Majra Colony $\mathbf{N}=83$

Physical violence( $\mathbf{N}=48)$

Slapped on cheeks/ head/ back

Pulled by hairs/ear/arms/leg

$27(56.25)$

Pushed / thrown things / choked

$23(47.92)$

Beaten with fist/ sticks/ rods/ utensils/ knife/ gun/ any other weapon

21( 26.58)

Kicked in chest/abdomen/ head or dragged

$14(17.72)$

Burnt any body part

\section{Psychological violence( $\mathbf{N}=68)$}

Jealous/angry on talking to other person

Frequently accuses/accused you of being unfaithful

$5(7.35)$

Does/did not permit you to meet your female friends

Tries/ tried to limit your contact with your family

22(32.35)

46(67.65)

Says/ does something to humiliate you in front of your family

10(14.70)

Threatened to harm/ hurt you or someone close to you 
Domestic Violence among Married Females: Prevalence and Related Factors

Insult you or make you feel inferior in front of others

$44(64.70)$

Uses inappropriate words against you or your relatives

$47(69.12)$

$3(4.41)$

Passes comments on your educational status to make you feel bad

$3(4.41)$

Passes comments on your occupational status to make you feel bad

$3(4.41)$

Financial abuse $(\mathbf{N}=\mathbf{2 3})$

Controls your access to money

14(60.87)

8(34.78)

$13(56.52)$

$3(13.04)$

Taken your valuables like gold, clothes etc. against your wish

Taken your salary forcibly from you

Sexual abuse( $\mathbf{N}=21)$

Any family member:

Passed comments on you

$4(19.04)$

Touched you in an inappropriate way

$1(4.76)$

By showing pornography

$1(4.76)$

Forced you to have sexual contact against your wish

$2(9.52)$

Your husband had sexual contact against your will

21(100.00)

*more than one method was used for abusing the female.

Table 3 Relationship of the Perpetrator with Female

\begin{tabular}{|c|c|c|c|}
\hline \multirow{2}{*}{$\begin{array}{l}\text { Relation of the abuser } \\
\text { with subject }\end{array}$} & Physical violence & Psychological violence & Sexual violence \\
\hline & $(\mathrm{N}=48) \quad n(\%)$ & $(\mathrm{N}=68) \quad \mathrm{n}(\%)$ & $(\mathrm{N}=21) \quad \mathrm{n}(\%)$ \\
\hline Husband & $44(91.67)$ & $51(75.00)$ & $21(100)$ \\
\hline Mother in law & $4(8.33)$ & $14(29.17)$ & - \\
\hline Father in law & - & $3(6.25)$ & $2(9.52)$ \\
\hline Brother in law & $2(4.17)$ & $3(6.25)$ & $2(9.52)$ \\
\hline Sister in law & $1(2.08)$ & $1(1.47)$ & - \\
\hline Daughter in law & $1(2.08)$ & $2(4.17)$ & - \\
\hline Children & $1(2.08)$ & $6(12.50)$ & - \\
\hline
\end{tabular}


Domestic Violence among Married Females: Prevalence and Related Factors

Table 4 Association between Socio Demographic Variables and Prevalence of Domestic Violence $(N=300)$

\begin{tabular}{|c|c|c|c|}
\hline Socio demographic variable & $\begin{array}{r}\text { Yes n(\%) } \\
\mathbf{N}=83\end{array}$ & $\begin{array}{r}\text { No n(\%) } \\
N=217\end{array}$ & Chi-square value ,df(p) \\
\hline \multicolumn{4}{|l|}{ Caste } \\
\hline General & 33(39.8) & 93(42.9) & \multirow{3}{*}{$4.641,2(0.098)$} \\
\hline Scheduled Caste/ tribe & $48(57.8)$ & $105(48.4)$ & \\
\hline Other backward classes & $2(2.4)$ & $19(8.8)$ & \\
\hline \multicolumn{4}{|l|}{ Religion } \\
\hline Hindu & $70(84.3)$ & 190(87.6) & \multirow{4}{*}{$7.459,2(0.024)$} \\
\hline Sikh & 12(14.5) & $14(6.5)$ & \\
\hline Others(Muslim/Christian/ Jainism) & $1(1.2)$ & $13(6.0)$ & \\
\hline \multicolumn{3}{|l|}{ Duration of marriage(years) } & \\
\hline$<1$ & $1(1.2)$ & $9(4.1)$ & \multirow{5}{*}{$2.797,4(0.592)$} \\
\hline $1-10$ & $32(38.6)$ & $77(35.5)$ & \\
\hline $11-20$ & 26(31.3) & $65(30.0)$ & \\
\hline $21-30$ & 18(21.7) & $42(19.4)$ & \\
\hline 31-40 and above & $6(7.2)$ & $24(11.1)$ & \\
\hline \multicolumn{4}{|l|}{ Total number of family members } \\
\hline 2 & $5(6.0)$ & $9(4.1)$ & \multirow{4}{*}{$0.633,3(0.889)$} \\
\hline $3-7$ & $65(78.3)$ & 177(81.6) & \\
\hline 8-12 & $12(14.5)$ & $29(13.4)$ & \\
\hline $13-17$ & $1(1.2)$ & $2(0.9)$ & \\
\hline \multicolumn{4}{|l|}{ Per capita income (rupees) } \\
\hline$<500$ & 26(31.3) & $43(19.8)$ & \multirow[t]{2}{*}{$4.491,1(0.034)$} \\
\hline 501-1500 and above & 57(68.7) & 174(80.2) & \\
\hline \multicolumn{4}{|l|}{ Type of family } \\
\hline Nuclear & $48(57.8)$ & $115(53.0)$ & \multirow{3}{*}{$0.567,1(0.452)$} \\
\hline Joint & $35(42.2)$ & 102(47.0) & \\
\hline \multirow{2}{*}{\multicolumn{4}{|c|}{$\begin{array}{l}\text { Marital status } \\
\text { Currently Married }\end{array}$}} \\
\hline & & & \\
\hline Others(Widow, Divorced, Separated) & $9(10.8)$ & $13(6.0)$ & \multirow{3}{*}{$2.080,1(0.149)$} \\
\hline \multirow{2}{*}{\multicolumn{3}{|c|}{$\begin{array}{l}\text { House ownership } \\
\text { Own }\end{array}$}} & \\
\hline & & & \\
\hline \multirow[t]{2}{*}{ Rented } & $67(80.7)$ & 172(79.3) & \multirow{2}{*}{$0.080,1(0.778)$} \\
\hline & 16(19.3) & 45(20.7) & \\
\hline
\end{tabular}


Domestic Violence among Married Females: Prevalence and Related Factors

Table 5 Association between Prevalence of Domestic Violence and Socio Demographic Variables of Husband and Wife ( $N=300)$

\begin{tabular}{|c|c|c|c|c|c|c|}
\hline \multirow[t]{2}{*}{ Variable } & \multicolumn{3}{|l|}{ husband } & \multicolumn{3}{|c|}{ Wife } \\
\hline & $\begin{array}{l}\text { Yes N=83 } \\
\text { n (\%) }\end{array}$ & $\begin{array}{l}\text { No } \\
\text { N=217 } \\
\text { n (\%) }\end{array}$ & $\begin{array}{l}\text { Chi square } \\
\text { value }\end{array}$ & $\begin{array}{l}\text { Yes } \\
\text { N=83 } \\
\text { n (\%) }\end{array}$ & $\begin{array}{l}\text { No } \\
\mathrm{N}=217 \\
\mathrm{n}(\%)\end{array}$ & $\begin{array}{l}\text { Chi square } \\
\text { value }\end{array}$ \\
\hline \multicolumn{7}{|l|}{ Age (years) } \\
\hline$<20$ and $21-30$ & $23(27.7)$ & $82(37.8)$ & & $18(21.7)$ & $52(24.0)$ & \\
\hline $31-40$ & $36(43.4)$ & $90(41.5)$ & $3.568,3(0.312)$ & $32(38.6)$ & $88(40.6)$ & $0.668,3(0.881)$ \\
\hline $41-50$ & $15(18.1)$ & $29(13.4)$ & & $24(28.9)$ & $53(24.4)$ & \\
\hline$>51$ & $9(10.8)$ & $16(7.4)$ & & $9(10.8)$ & 24(11.1) & \\
\hline \multicolumn{7}{|l|}{ Educational status } \\
\hline Illiterate & $7(8.4)$ & $12(5.5)$ & & $3(3.6)$ & $10(4.6)$ & \\
\hline Just literate & 14(16.9) & $45(20.7)$ & & $1(1.2)$ & $9(4.1)$ & \\
\hline Primary & $7(8.4)$ & $17(7.8)$ & & $7(8.4)$ & $13(6.0)$ & \\
\hline Middle & $28(33.7)$ & $44(20.3)$ & $8.265,5(0.142)$ & $30(36.1)$ & $39(18.0)$ & $14.216,5(0.014)$ \\
\hline Metric & $13(15.7)$ & $48(22.1)$ & & $16(19.3)$ & 67(30.9) & \\
\hline Higher secondary and above & 14(16.9) & $51(23.5)$ & & 26(31.3) & $79(36.4)$ & \\
\hline \multicolumn{7}{|l|}{ Occupation } \\
\hline Housewife/ unemployed & $71(85.5)$ & 183(84.3) & & $2(2.4)$ & $3(1.4)$ & \\
\hline Maid/part time & $3(3.6)$ & 7( 3.2$)$ & & $6(7.2)$ & $13(6.0)$ & \\
\hline worker/Labourer & $3(3.6)$ & $10(4.6)$ & $0.218,4(0.994)$ & 26(31.3) & $45(20.7)$ & $8.109,4(0.088)$ \\
\hline Self employed & $3(3.6)$ & $9(4.1)$ & & $41(49.4)$ & $109(50.2)$ & \\
\hline $\begin{array}{l}\text { Private job } \\
\text { Government job/ retired }\end{array}$ & $3(3.6)$ & $8(3.7)$ & & $8(9.6)$ & $47(21.7)$ & \\
\hline
\end{tabular}

How to cite this article: M Kaur, D Kapoor, J Kaur, P Gautam, S Sharma, S Saini, S Bamania (2016), Domestic Violence among Married Females: Prevalence and Related Factors, International Journal of Indian Psychology, Volume 3, Issue 4, No. 74, ISSN:2348-5396 (e), ISSN:2349-3429 (p), DIP:18.01.021/20160304, ISBN:978-1-365-46362-4 